\title{
A citokeratin-18 sejthalálmarker vizsgálata sikeres cardiopulmonalis resuscitatión átesett betegpopulációban
}

\author{
Csiszár Beáta dr., ${ }^{1,2}$. Németh Álmos dr. ${ }^{3}$ - Márton Zsolt dr. ${ }^{1,4}$ \\ Riba János $\mathrm{dr}^{4}{ }^{4}$ - Csécsei Péter $\mathrm{dr} .^{5}$ - Molnár Tihamér $\mathrm{dr} .{ }^{6}$ \\ Deres László dr. ${ }^{1,2}$. Halmosi Róbert dr. ${ }^{1,2}$ \\ Tóth Kálmán dr. ${ }^{1,2}$. Kenyeres Péter dr. ${ }^{1,2}$ \\ ${ }^{1}$ Pécsi Tudományegyetem, Klinikai Központ, I. Belgyógyászati Klinika, \\ Kardiológiai Tanszék és Angiológiai Tanszék, Pécs \\ ${ }^{2}$ Pécsi Tudományegyetem, Szentágothai János Kutatóközpont, Pécs \\ ${ }^{3}$ Pécsi Tudományegyetem, Általános Orvostudományi Kar, Pécs \\ ${ }^{4}$ Pécsi Tudományegyetem, Klinikai Központ, I. Belgyógyászati Klinika, Belgyógyászati Intenzív Osztály, Pécs \\ ${ }^{5}$ Pécsi Tudományegyetem, Klinikai Központ, Neurológiai Klinika, Pécs \\ ${ }^{6}$ Pécsi Tudományegyetem, Klinikai Központ, Aneszteziológiai és Intenzív Terápiás Intézet, Pécs
}

\begin{abstract}
Bevezetés: Citokeratin-18 (CK-18) az újraélesztés kapcsán kialakuló ischaemiás-reperfúziós károsodás kiváltotta teljes sejthalál során kerül a véráramba. Kaszpázok által hasított formája specifikus az apoptózis folyamatára. A markerek számos kórképben prognosztikus értékúnek bizonyultak. Tanulmányunkban elsőként vizsgáltuk prognosztikus értéküket reanimált betegpopulációban.

Módszer: 40, sikeresen újraélesztett betegnél határoztuk meg a sejthalálmarkerek szintjét 6 órán belül, 24 és 72 óra múlva. Ezeket összevetettük a 30 napos túléléssel, a neurológiai kimenetellel, a szervfunkciós károsodást jellemző laboratóriumi, fizikális és terápiás jellemzőkkel, valamint a reanimáció körülményeivel.

Eredmények: A reanimált betegek CK-18-plazmakoncentrációja a szakirodalomban leírt egészséges, posztoperatív és szeptikus populáció értékeinek a többszöröse volt ( 3842 vs. $242 ; 559 ; 1644 \mathrm{ng} / \mathrm{l})$; a hasított és intakt CK-18 aránya alacsonyabb volt $(0,14$ vs. 0,$58 ; 0,22 ; 0,24)$, ami jelentős sejtkárosodásra és a nekrózis dominanciájára utal. A markerek szintje azonban nem mutatott összefüggést a túléléssel, a neurológiai statusszal és a reanimáció körülményeivel sem. Veseelégtelenség esetén a CK-18 szintjének csökkenése elmaradt. Szignifikáns negatív korrelációt figyeltünk meg a 6 órás hemoglobin- és CK-18-szint között $(\mathrm{r}=-0,400, \mathrm{p}<0,01)$, a 30 napos túlélésnek mégis az alacsonyabb hemoglobinértékek kedveztek.

Következtetés: Várakozásunkkal ellentétben a vizsgált markerek nem bírtak prognosztikus értékkel újraélesztett betegpopulációban. A kimenetelt valószínúleg nem a teljes sejtkárosodás, hanem egy kisebb, a fenti markerekkel szenzitíven nem vizsgálható kritikus szerepú sejtpopuláció károsodása, valamint a beteg tartalékkapacitásai befolyásolják.

Orv Hetil. 2020; 161(1): 26-32.
\end{abstract}

Kulcsszavak: újraélesztés, citokeratin-18, prognózis

\section{The prognostic value of cytokeratin-18 cell death marker in cardiac arrest survivors}

Introduction: Cytokeratin-18 (CK-18) is releasing into the blood during systemic cell death due to ischemia-reperfusion injury after cardiac arrest. Its caspase-cleaved form is specific to apoptosis. Previous investigations proved their prognostic value in different conditions. We firstly investigated the prognostic value of these markers after cardiac arrest.

Method: Plasma samples of 40 resuscitated patients were collected 6, 24, and 72 hours after successful resuscitation to determine the marker concentrations. We investigated the association of the markers with the 30-day mortality, neurological outcome, circumstances of the cardiac arrest, laboratory and physical parameters.

Results: Resuscitated patients had highly elevated CK-18 levels (3842 vs. $242 ; 559 ; 1644 \mathrm{ng} / \mathrm{L})$ and decreased caspase-cleaved CK-18/CK-18 ratio $(0.14$ vs. $0.58 ; 0.22 ; 0.24)$ compared to healthy subjects, septic and postoperative 
patients suggesting severe grade of cell death, mainly necrosis. Neither the marker concentrations nor their kinetics showed difference between survivors and non-survivors. They did not show association with the length of the resuscitation, the initial rhythm or the neurological outcome either. CK-18 decreased in patients with good renal function in contrast to patients with renal failure. Significant negative correlation was observed between the 6-hour cytokeratin-18 and hemoglobin concentrations $(\mathrm{r}=-0.400, \mathrm{p}<0.01)$, while the 30 -day survival was associated with lower hemoglobin levels.

Conclusion: Surprisingly the biomarkers did not show prognostic value among resuscitated population. The outcome is probably not determined by the complete cell damage, but the loss of a small group of cells with critical role and the reserve capacity of the patient.

Keywords: resuscitation, cytokeratin-18, prognosis

Csiszár B, Németh Á, Márton Zs, Riba J, Csécsei P, Molnár T, Deres L, Halmosi R, Tóth K, Kenyeres P. [The prognostic value of cytokeratin-18 cell death marker in cardiac arrest survivors]. Orv Hetil. 2020; 161(1): $26-32$.

(Beérkezett: 2019. június 24.; elfogadva: 2019. augusztus 5.)

\section{Rövidítések}

$\mathrm{BE}=($ base excess) bázistöbblet; ccCK-18 = (caspase-cleaved CK-18) kaszpázok által hasított CK-18; CK-18 = (cytokeratin-18) citokeratin-18; $\mathrm{CKD}=$ (chronic kidney disease) krónikus vesebetegség; COPD $=$ (chronic obstructive pulmonary disease) krónikus obstruktív tüdőbetegség; CPC = Cerebral Performance Category; $\mathrm{CPR}=$ cardiopulmonalis resuscitatio; $\mathrm{CRP}=\mathrm{C}$-reaktív protein; EDTA = etilén-diamin-tetraecetsav; eGFR $=($ estimated glomerular filtration rate $)$ becsült glomerulusfiltrációs ráta; ELISA = (enzyme-linked immunosorbent assay) enzimhez kötött ellenanyag-vizsgálat; GOT = glutamátoxálacetát-aminotranszferáz; GPT = glutamát-piruvát-aminotranszferáz; IHCA = (in hospital cardiac arrest) kórházon belüli szívleállás; INR $=$ (international normalized ratio) nemzetközileg normalizált ráta; ISZB = ischaemiás szívbetegség; $\mathrm{IQR}=$ (interquartile range) interkvartilis tartomány; $\mathrm{LDH}$ = laktátdehidrogenáz; NSE = neuronspecifikus enoláz; OHCA $=$ (out of hospital cardiac arrest) kórházon kívüli szívleállás; $\mathrm{PaCO}_{2}=\mathrm{az}$ artériás szén-dioxid parciális nyomása; $\mathrm{PaO}_{2}=\mathrm{az}$ artériás oxigén parciális nyomása; $\mathrm{PCT}=$ prokalcitonin; $\mathrm{PEA}=$ (pulseless electrical activity) pulzus nélküli elektromos aktivitás; S100B = (S100 calcium-binding protein B $)$ S100 kalciumkötó fehérje $\mathrm{B}$ típusa; TIA = (transient ischemic attack) átmeneti ischaemiás roham

A klinikai halál állapotában a szöveti perfúzió és oxigenizáció a sejtélethez szükséges kritikus szint alá csökken. A kialakult hypoxiás periódus és az energiahiány beindítja a sejthalál folyamatát, mely a sejtet ért károsító hatástól függően két úton mehet végbe. Nekrózis esetében a stresszhatás fatális mértékű, a sejt elveszti integritását, és a környezetbe kerülő sejtalkotók gyulladásos reakciót indukálnak, mely a környezet további károsodását okozza. $\mathrm{Az}$ apoptózis sejtszinten szabályozott, energiaigényes folyamat, melyet a sejtet korlátozott mértékben érő károsodás indít be. A sejt intakt membránnal határolt részekre - apoptotikus testekre - esik szét, amelyeket a környező szövet sejtjei kebeleznek be és bontanak le gyulladásos reakció nélkül. Fontos elemei a kaszpázcsalád enzimei, melyek a haláljel kaszkádszerű felerősítésében és a célfehérjék hasításában vesznek részt [1].
A cytoskeletalis, intermedier filamentumokhoz tartozó citokeratin-18 (CK-18) fóként epithelialis és parenchymás sejtekben expresszálódik. Apoptózis során a CK-18-at a kaszpázok több helyen hasítják, és a fragmentumok a vérben kimutathatóvá válnak. Teljes hoszszúságú CK-18 nekrózis során kerül a véráramba, míg hasított formája (caspase-cleaved cytokeratin-18 - ccCK18 ) kizárólag apoptózis során szabadul fel [2].

A ccCK-18 szerepét számos kórállapotban vizsgálták, többek között szeptikus betegcsoportban, akut myocardialis infarctusban, májbetegségekben, krónikus vesebetegekben [3-6]. A szérum-ccCK-18 aneurysmaruptura miatti subarachnoidealis vérzés, valamint intracerebralis haemorrhagia során is emelkedett értékeket mutatott, a 6 hónapos mortalitás és a kedvezőtlen kimenetel független prediktorának bizonyult $[7,8]$. Ischaemiás strokeban a 72 óra után mért ccCK-18-értékek szignifikánsan magasabbak voltak az elhunytak körében [9].

$\mathrm{Az}$ újraélesztést követően gyakori szövődmény a hypoxiás-ischaemiás agykárosodás, mely tartós vegetatív állapot kialakulásához és halálhoz vezethet. Erre utaló kifejezetten kedvezőtlen prognózis esetén az életfenntartó kezelés aktív megvonására, így a terápiás erőfeszítések csökkentésére kerülhet sor, tehát nem történik új terápiás lépés bevezetése, és a létfenntartó, szervtámogató kezelés további kiterjesztését mellőzzük. A döntés súlya miatt nagyon fontos a hamisan rossz prognózis elkerülése. A legújabb irányelvek alapján a prognózis a fizikális paramétereken, elektrofiziológiai és elektroencefalográfiás, valamint agyi képalkotó eljárásokon alapul. Emellett a neuronspecifikus enoláz (NSE) és az S100B biomarkerek szerepét is felvetik, az ezekkel kapcsolatos határértékek azonban nem egyértelmúek. Szükség van olyan új markerek azonosítására, melyek a prognózis helyességét tovább erósítik $[10,11]$. Sikeres reanimáción átesett betegpopulációval kapcsolatban nincs szakirodalmi adat a CK-18 és ccCK-18 prediktív értékét illetően, így a markerek használhatóságát elsőként vizsgáltuk.

Hipotézisünk szerint a klinikai halál állapotában, a spontán keringés helyreállításáig bekövetkező nagyobb 
szöveti károsodás nagyobb funkcionális károsodáshoz, rosszabb túléléshez és jelentősebb maradványtünetekhez vezet. A szisztémás szöveti károsodást a sejthalál mértékére utaló CK-18- és ccCK-18-szintekkel jellemezhetjük. Feltételeztük, hogy a markerek koncentrációja és kinetikája prognosztikai értékkel bírhat a resuscitatiót követő mortalitás, illetve funkcionális károsodás előrejelzésében. Vizsgálni kívántuk, hogy a CK-18-, ccCK18-szintek milyen összefüggésben állnak a rendelkezésre álló egyéb, gyakran használt klinikai és biokémiai markerekkel, szervfunkciós paraméterekkel.

\section{Módszer}

Vizsgálatunkba 40 beteget vontunk be, akiknél kórházon belül vagy azon kívül történt minimum 2 percig tartó sikeres újraélesztés, és postresuscitatiós kezelésüket a Pécsi Tudományegyetem Klinikai Központja I. Belgyógyászati Klinikájának Belgyógyászati Intenzív Osztályán, Sürgősségi Betegellátó Osztályán vagy Aneszteziológiai és Intenzív Terápiás Intézetében kezdték meg. Kizárásra kerültek azok a betegek, akiknél reanimáció előtt jelentős szövetroncsolódás (politraumatizált, égett, korai posztoperatív betegek) vagy a beteg várható hosszú távú funkcionális állapotát eleve jelentősen rontó súlyos előzetes neurológiai kórkép állt fenn, illetve akiknél a hemodinamikai állapotot nem sikerült stabilizálni, így egynapos túlélés sem volt várható, vagy a vizsgálatba való vélelmezett beleegyezését a beteg vagy családja megtagadta. A betegút jellegéból fakadóan nem voltak reprezentálva a vélhető akutcoronaria-szindróma miatt újraélesztést követően azonnal a perkután intervenció irányába továbbított betegek sem. A vizsgálatban részt vevők terápiás hypothermiában nem részesültek, azonban a hyperthermia prevenciójára a klinikai gyakorlatnak megfelelően minden esetben fokozottan ügyeltünk.

A reanimációt követően 6 órán belül, majd $24 \pm 3$ és $72 \pm 3$ óra múlva történt vérvétel a ccCK-18, CK-18 markerek szintjének meghatározására (EDTA-val antikoagulált, a feldolgozásig $-80{ }^{\circ} \mathrm{C}$-on tárolt plazmából; 'human caspase-cleaved cytokeratin-18' [ccCK-18] és 'cytokeratin-18' [CK-18] ELISA Kit, YL Biotech Co., Ltd., Shanghai, Kína). A CK-18 ELISA Kit esetében az intakt és a hasított formájú CK-18 koncentrációja, így a teljes sejthalál mértéke határozható meg, míg ccCK18-mérésnél csak a kaszpázok által hasított fehérjét detektáljuk. A ccCK-18/CK-18 arányból következtethetünk a nekrózis mértékére.

Rögzítésre kerültek a rutin-betegellátás során vizsgált, a reanimációt követő $6 ., 24$. és 72 . órás mintavételekhez időben legközelebb eső aznapi laborparaméterek: elektrolitok - nátrium, kálium, karbamid, kreatinin; troponin-T; a GOT-, GPT-, LDH-, INR-, CRP-, PCT-, vérkép- és vérgázértékek $\left(\mathrm{pH}, \mathrm{PaO}_{2}, \mathrm{PaCO}_{2}, \mathrm{BE}\right)$, laktát. Emellett rögzítettük a reanimáció körülményeit (a CPR időhossza, az alkalmazott gyógyszerek, feltételezett etiológia, kezdeti ritmus), a beteg teljes körü anamnézisét,
1. táblázat A Cerebral Performance Category-skála a neurológiai status megítélésére $P$. Safar Resuscitation after brain ischemia közleménye alapján [12]

CPC 1. Jó agyi funkció. A tudat megtartott, a beteg éber, képes dolgozni és normális életvitelt folytatni. Esetleg minimális pszichológiai vagy neurológiai deficit áll fenn.

CPC 2. Mérsékelt cerebralis funkciózavar. A tudat megtartott. A mindennapi önálló életvitelhez szükséges kielégítő agyi funkciók. A beteg részidőben történő munkavégzésre alkalmas speciális körülmények között.

CPC 3. Súlyos cerebralis funkciózavar. A beteg mások segítségét igényli a mindennapokban (intézményen belül, vagy otthon rendkívüli családi segítséggel). A kategória széles tartományt ölel fel az enyhe kognitív zavartól egészen a súlyos dementiáig, paralízisig.

CPC 4. Eszméletlen betegek (kóma vagy vegetatív állapot), akik környezetüket nem észlelik, arra nem reagálnak. Nem figyelhető meg verbális vagy pszichológiai interakció semmilyen formában. Az agyhalál minden kritériumát nem meríti ki.

CPC 5. Agyhalál, csupán a keringés megtartott. Apnoe, areflexia, EEG-jelek hiánya stb.

EEG = elektroencefalográfia

ismert betegségeit, az ellátás során alkalmazott gyógyszereket és beavatkozásokat, az intenzív osztályos kezelés hosszát. Vizsgálati végpontnak a 30 napon belüli halálozást tekintettük. Betegeink funkcionális és neurológiai állapotának megítéléséhez az 1. táblázatban részletezett Cerebral Performance Category (CPC)-besorolást használtuk [12]. Az ellátás során a betegnél észlelt legjobb CPC-értéket jegyeztük fel. A vizsgálat protokollját a Regionális Kutatásetikai Bizottság jóváhagyta engedélyszám: 6941-PTE 2018.

A statisztikai értékelésnél a folytonos változók esetén a medián értékeket, valamint az interkvartilis tartományt (IQR), a kategorikus változóknál a gyakoriságot és a százalékos előfordulást tüntettük fel. A csoportok összehasonlítását a Mann-Whitney-féle nemparaméteres próbával végeztük a nem normális eloszlást mutató adatoknál. A kategorikus változók kapcsolatának kiértékelése khinégyzet-próbával történt. A folytonos változók közötti kapcsolat megítélésére a nemparaméteres Spearman-féle korrelációs koefficienst (rho), valamint az ehhez tartozó p-értékeket összegeztük. Az eltéréseket és az összefüggéseket $\mathrm{p}<0,05$ esetén tekintettük szignifikánsnak.

\section{Eredmények}

A CPR helyszíne alapján a 40 vizsgálati alany közül 29 esetben $(72,5 \%)$ kórházon belül (IHCA), 11 betegnél $(27,5 \%)$ pedig kórházon kívül (OHCA) történt a reanimáció. Az esemény 31 esetben $(77,5 \%)$ ügyeleti időre vagy hétvégére esett. Az iniciális ritmus 13 esetben $(32,5 \%)$ volt sokkolható kamrai tachycardia vagy kamrafibrilláció, 25 betegnél $(62,5 \%)$ PEA vagy asystolia, 
A 30 napot túlélt és 30 napon belül elhunyt betegcsoport jel lemzői (medián és [IQR])

\begin{tabular}{llll}
\hline & $\begin{array}{l}30 \text { napot túlélók } \\
(\mathrm{n}=14)-35 \%\end{array}$ & $\begin{array}{l}30 \text { napon belül } \\
\text { elhunytak } \\
(\mathrm{n}=26)-65 \%\end{array}$ & $\begin{array}{l}\text { Szignifikancia } \\
(\mathrm{p} \text {-érték) }\end{array}$ \\
\hline Nói nem - fó (\%) & $10(71,4 \%)$ & $13(50,0 \%)$ & N.S. \\
Életkor (év) & $61[58-77]$ & $66[62-79]$ & N.S. \\
CPR (perc) & $10,0[5,0-30,0]$ & $10,0[5,0-20,0]$ & N.S. \\
max. CPC-érték & $3[3-3]$ & $5[4-5]$ & 0,001 \\
\hline
\end{tabular}

$\mathrm{CPC}=$ Cerebral Performance Category; $\mathrm{CPR}=$ cardiopulmonalis re suscitatio; IQR = interkvartilis tartomány; N.S. = nem szignifikáns

2 esetben pedig nem sikerült ezt kiderítenünk. Rövid reanimáció ( $\leq 10$ perc) 18 esetben $(53 \%)$, hosszú (>10 perc) reanimáció 16 esetben $(47 \%)$ történt; 6 esetben nem tudtunk megbízható információt nyerni ennek hosszáról. A százalékos adatok az ismert esetek megoszlására utalnak. Az etiológiát tekintve 52,4\%-ban cardialis ok (ISZB, szívelégtelenség) miatt következett be keringés- és légzésleállás. A további okok között ionzavarok (hyperkalaemia), aspiráció, hypothermia, tüdőembolia fordult elő. A betegek egy részénél nem sikerült egyértelmûen azonosítani a kiváltó tényezőt. A komorbiditást illetően magasvérnyomás-betegség (70\%), ISZB (42,5\%), 2 -es típusú diabetes mellitus $(37,5 \%)$, szívelégtelenség $(32,5 \%)$, permanens pitvarfibrilláció $(22,5 \%)$, stroke vagy TIA $(17,5 \%)$, COPD $(17,5 \%)$, perifériás artériás érbetegség $(12,5 \%)$, pulmonalis embolia $(7,5 \%)$ fordult elő az anamnézisben.

A 2. táblázatban összegeztük a túlélők és az elhunytak demográfiai adatait, a resuscitatio hosszát és a neurológiai kimenetelt. A nemet és az életkort illetően nem volt szignifikáns különbség a túlélők és az elhunytak között, az újraélesztés időtartama sem különbözött a két csoportban. A CPC-skála alapján felmért neurológiai status, így a 30 nap során elért legjobb CPC-kategória a túlélőknél szignifikánsan kedvezőbb volt. Összességében az egyes kategóriákban a megoszlás a következőképpen alakult: CPC 1.: 1 eset, CPC 2.: 2 eset, CPC 3.: 16 eset, CPC 4.: 6 eset, CPC 5.: 15 eset.

A laboratóriumi paraméterek közül az elhunytak 6 . órás troponin-T-, transzamináz-, INR-, fehérvérsejt-, 24 . és 72. órás hemoglobin-, valamint 6. és 24 . órás laktátértékei bizonyultak szignifikánsan magasabbnak (3. táblázat). Az egyes értékek más időpontokban szignifikáns különbséget nem mutattak. Az 1. és 2. ábrán a 6 órán belül, a 24 ., illetve 72 . órás időpontban mért CK-18- és ccCK-18-értékeket ábrázoltuk a túlélés szerinti bontásban. Az egyes csoportok között nem találtunk statisztikailag szignifikáns különbséget, és érdemi változást sem tapasztaltunk a 3 mérési időpont között. Vizsgálatunk során a maximális CPC-pontszám, így a neurológiai kimenetel sem mutatott összefüggést a biomarkerek szintjével. A reanimáció hossza sem befolyásolta a sejthalálmarkerek szintjét.
3. táblázat A 30 napot túlélt és 30 napon belül elhunyt betegcsoport laboratóriumi jellemzói (medián és [IQR])

\begin{tabular}{|c|c|c|c|}
\hline $\begin{array}{l}\text { Laboratóriumi } \\
\text { paraméterek, } \\
\text { medián [IQR] }\end{array}$ & $\begin{array}{c}30 \text { napot } \\
\text { túlélők } \\
(\mathrm{n}=14)-35 \%\end{array}$ & $\begin{array}{l}30 \text { napon belül } \\
\text { elhunytak } \\
(\mathrm{n}=26)-65 \%\end{array}$ & $\begin{array}{l}\text { Szignifikancia } \\
\text { (p-érték) }\end{array}$ \\
\hline $\begin{array}{l}\text { Troponin-T }(\mathrm{ng} / \mathrm{l}) \\
6 \mathrm{~h}\end{array}$ & $\begin{array}{c}45,0 \\
{[26,4-140,2]}\end{array}$ & $\begin{array}{c}158,9 \\
{[50,1-441,0]}\end{array}$ & 0,038 \\
\hline $\operatorname{GOT}(\mathrm{U} / \mathrm{l}) 6 \mathrm{~h}$ & $\begin{array}{c}26,0 \\
{[23,0-93,0]}\end{array}$ & $\begin{array}{c}109,0 \\
{[49,0-726,0]}\end{array}$ & 0,002 \\
\hline GPT $(\mathrm{U} / \mathrm{l}) 6 \mathrm{~h}$ & $\begin{array}{c}18,0 \\
{[13,0-114,0]}\end{array}$ & $\begin{array}{c}93,5 \\
{[26,5-764,5]}\end{array}$ & 0,026 \\
\hline INR $6 \mathrm{~h}$ & $1,2[1,0-1,3]$ & $1,4[1,1-1,9]$ & 0,047 \\
\hline $\begin{array}{l}\text { Fehérvérsejtszám } \\
\text { (Giga/l) } 6 \mathrm{~h}\end{array}$ & $\begin{array}{c}11,2 \\
{[8,7-15,4]}\end{array}$ & $\begin{array}{c}16,1 \\
{[10,9-23,8]}\end{array}$ & 0,046 \\
\hline $\begin{array}{l}\text { Hemoglobin }(\mathrm{g} / \mathrm{l}) \\
24 \mathrm{~h}\end{array}$ & $\begin{array}{c}100,0 \\
{[84,8-120,5]}\end{array}$ & $\begin{array}{c}119,0 \\
{[109,0-134,0]}\end{array}$ & 0,012 \\
\hline $\begin{array}{l}\text { Hemoglobin }(\mathrm{g} / \mathrm{l}) \\
72 \mathrm{~h}\end{array}$ & $\begin{array}{c}95,5 \\
{[80,3-116,0]}\end{array}$ & $\begin{array}{c}113,0 \\
{[102,0-125,0]}\end{array}$ & 0,023 \\
\hline $\begin{array}{l}\text { Hematokrit }(\%) \\
24 \mathrm{~h}\end{array}$ & $\begin{array}{c}30,0 \\
{[26,1-38,7]}\end{array}$ & $\begin{array}{c}36,6 \\
{[33,4-41,9]}\end{array}$ & 0,007 \\
\hline $\begin{array}{l}\text { Hematokrit (\%) } \\
72 \mathrm{~h}\end{array}$ & $\begin{array}{c}29,7 \\
{[24,7-35,9]}\end{array}$ & $\begin{array}{c}37,2 \\
{[32,0-40,5]}\end{array}$ & 0,025 \\
\hline $\begin{array}{l}\text { Laktát }(\mathrm{mmol} / \mathrm{l}) \\
6 \mathrm{~h}\end{array}$ & $3,1[2,0-5,2]$ & $7,7[5,0-10,7]$ & 0,003 \\
\hline $\begin{array}{l}\text { Laktát }(\mathrm{mmol} / \mathrm{l}) \\
24 \mathrm{~h}\end{array}$ & $1,1[0,8-1,5]$ & $1,8[1,1-2,4]$ & 0,027 \\
\hline
\end{tabular}

GOT = glutamát-oxálacetát-aminotranszferáz; GPT = glutamát-piruvát-aminotranszferáz; INR = nemzetközileg normalizált ráta; IQR = interkvartilis tartomány

Veseelégtelenség (beszúkült vizeletprodukció $[<500$ $\mathrm{ml} /$ nap] vagy $30 \mathrm{ml} /$ perc alatti eGFR) esetén a CK-18 koncentrációja változatlanul magas értéket mutatott a 72 óra során. Ép vesefunkció mellett a marker szintje csökkent, és a 72. órára szignifikánssá vált a különbség a két csoport között (veseelégtelen: 4021,0 [3535,3-

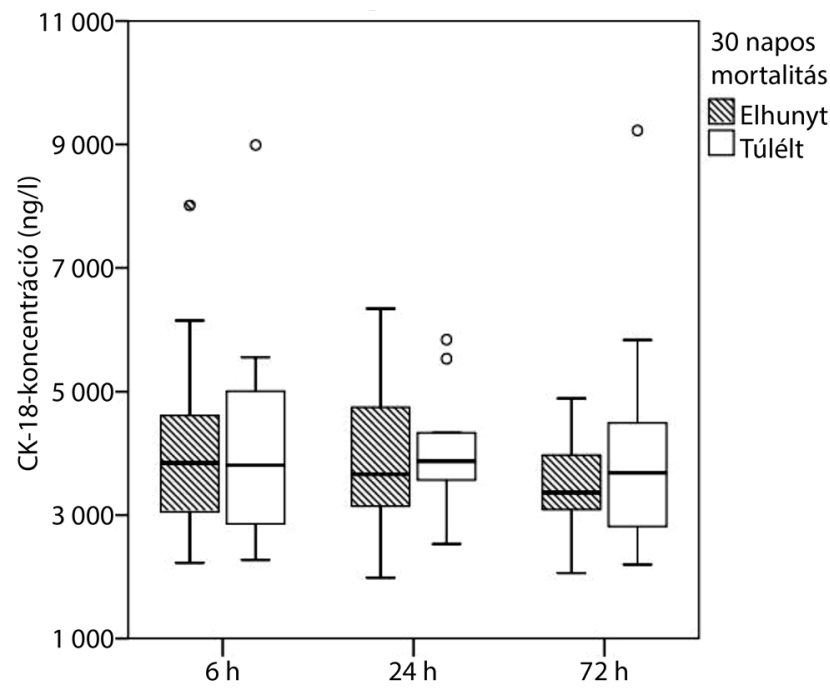

1. ábra | CK-18-koncentrációk a 3 mintavételi időpontban 


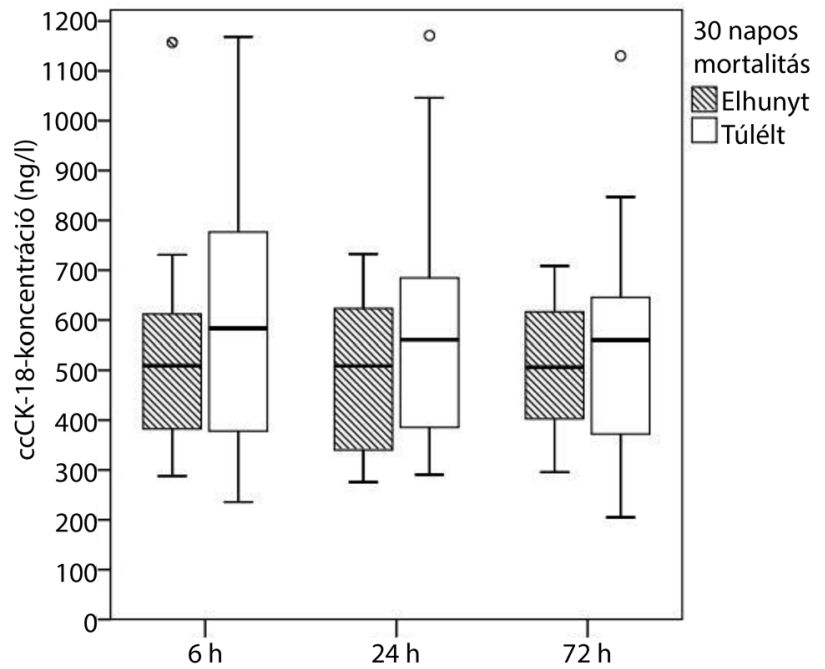

2. ábra | ccCK-18-koncentrációk a 3 mintavételi időpontban

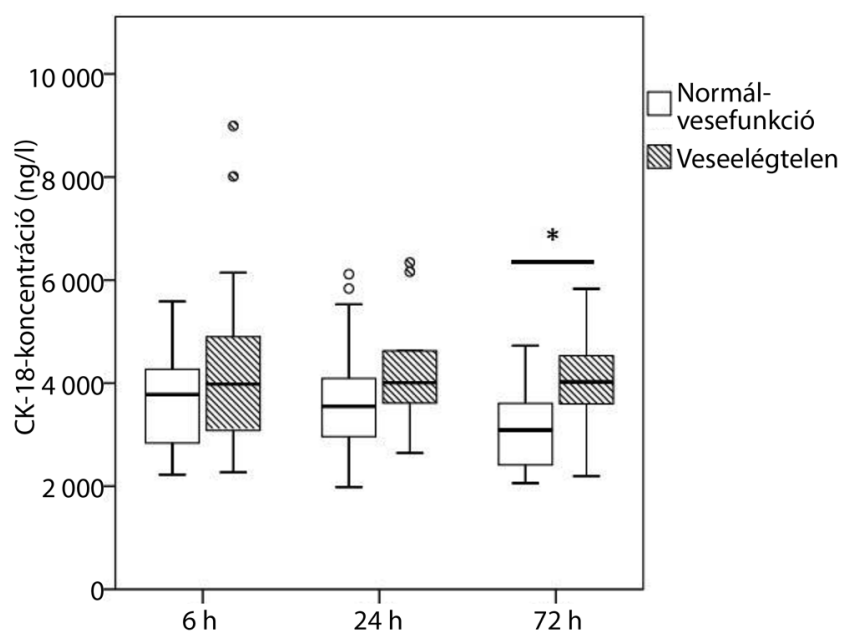

3. ábra

| CK-18-koncentrációk és vesefunkció

${ }^{*} \mathrm{p}=0,022$

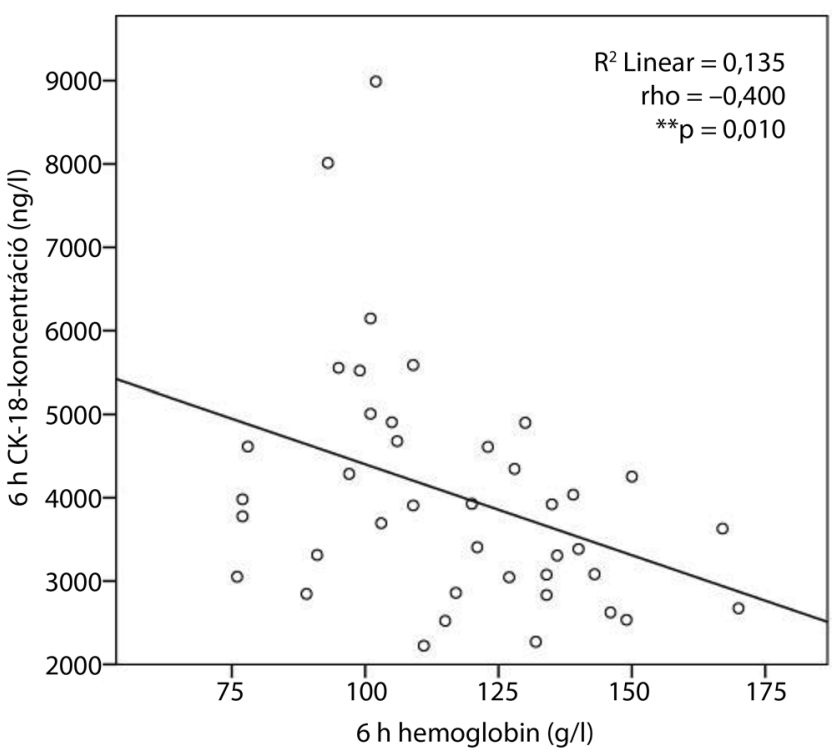

4. ábra $\quad$ CK-18-koncentrációk és hemoglobin
$4710,8] \mathrm{ng} / \mathrm{l}$ vs. $3088,0[2401,5-3786,5] \mathrm{ng} / \mathrm{l} ; \mathrm{p}=$ $0,022)$ (3. ábra).

A CK-18- és a hemoglobinszint között szignifikáns negatív korrelációt figyeltünk meg ( $\mathrm{rho}=-0,400 ; \mathrm{p}=$ 0,010) (4. ábra).

\section{Megbeszélés}

A rövidebb reanimáció az általános vélekedés szerint jobb prognózist jelent. A várttal ellentétben vizsgálatunkban a reanimáció hossza sem a kimenetelt, sem a sejthalálmarkerek szintjét nem befolyásolta, a túlélők és az elhunytak esetében azonos átlagos reanimációs időt találtunk. Vizsgálatunkban azonban nem reprezentáltak az igen rövid (<2 perc) újraélesztések, amelyeknél a beteg gyorsan és gyakran azonnali kielégítő tudattal tér vissza (például gyorsan terminálódó ritmuszavar esetén), és definitív intenzív terápiás postresuscitatiós kezelést nem igényel. A „rövid” (<l0 perc) csoporton belül csak 5 alany részesült 5 percnél rövidebb reanimációban, 13 esetben ez 5-10 perc volt. A felosztás azt sem veszi figyelembe, hogy mekkora volt a légzés-keringés megállás beállta és az újraélesztés megkezdése közt eltelt hypoxiás idő, vagy a keringésleálláshoz esetlegesen vezetố megelőző hypoxia mértéke.

Roblin és mtsai a kórházon belül történt szívmegállások esetében kapcsolatot találtak a rövidebb reanimáció és a jobb 30 napos túlélés között, viszont 30 percet meghaladó CPR esetében is a vártnál magasabb túlélési arányt figyeltek meg, így önmagában a CPR időtartama csekély prognosztikus értékkel bír [13]. A várható kimenetel nem feltétlenül a spontán keringés visszatéréséig eltelt időtől, hanem a páciensek általános állapotától, a klinikai halálhoz vezető egyéb tényezőktől függhet.

A reanimációt követóen a neurológiai statust jellemző CPC-értéket 30 napig követtük, és a legjobb elért értéket vettük alapul [14]. Nem meglepó módon a túlélók szignifikánsan jobb pontszámot értek el, de még ez is alatta marad a szakirodalomban fellelhetô adatoknak. Azon vizsgálatokban viszont az elbocsátáskori CPC-értéket elemezték [15]. A jobb értékek hátterében a 30 napot túlélő betegek további kezelése során elért javulás állhat, illetve a később visszaeső és elhunyt betegek gyengébb értékeinek kiszelektálódása.

Számos élettani és biokémiai paraméter mutatott a feltételezettnek megfelelő szignifikáns vagy tendenciózus romlást az elhunytak körében. A troponin-T a myocardialis sérülést, a GOT-, GPT-, INR-értékek a máffunkció károsodását, a laktát és bizonyos fokig a GOT, GPT a globális szöveti perfúzió romlását, a diffúz szövetsérülést jelezheti. A 30 napos túlélés szempontjából az alacsonyabb hemoglobinértékek tüntek kedvezőbbnek. Feltételezhetően az enyhén csökkent hemoglobin (és hematokrit) következtében csökkenő viszkozitás kedvezőbb mikrocirkulációt biztosít szöveti szinten.

Betegeink összesített CK-18- és ccCK-18-szintjei jóval magasabbnak bizonyultak a szakirodalomban leírt 
A 6. órás CK-18-, ccCK-18-értékek és arányuk összehasonlítva más vizsgálatban tapasztalt egészséges kontroll-normáltartománnyal, a posztoperatív és a szeptikus betegcsoport értékeivel [16] (medián és [IQR])

\begin{tabular}{|c|c|c|c|c|}
\hline & \multirow{2}{*}{$\begin{array}{c}\text { A } 6 \text { órán belül mért } \\
\text { markerszintek } \\
\text { vizsgálatunkban }\end{array}$} & \multicolumn{3}{|c|}{ Szakirodalmi adatok [16] } \\
\hline & & Egészséges kontroll & Posztoperatív & Szeptikus \\
\hline CK-18 (ng/1) & $3842,5[3047,5-4662,8]$ & $241,9[216,9-285,3]$ & $558,7[465,6-793,0]$ & $1643,8[1096,5-2633,5]$ \\
\hline ccCK-18 (ng/l) & $532,9[378,9-646,9]$ & $143,7[134,4-168,1]$ & $116,0[106,6-165,1]$ & $392,6[258,4-654,5]$ \\
\hline ccCK-18/CK-18 arány & $0,14[0,11-0,18]$ & $0,58[0,55-0,67]$ & $0,22[0,18-0,25]$ & $0,24[0,14-0,35]$ \\
\hline
\end{tabular}

ccCK-18 = kaszpázok által hasított CK-18; CK-18 = citokeratin-18

egészséges, posztoperatív, illetve szeptikus alanyokéihoz képest, ami nagy mértékű szöveti károsodásra utal. A ccCK-18/CK-18 arány jelentősen alacsonyabbnak mutatkozott, amiből a nekrotikus sejthalál dominanciájára következtethetünk (4. táblázat) [16]. A markerek nem mutattak összefüggést sem a halálozással, sem a CPCskála szerinti neurológiai besorolással, így prognosztikus értékük az újraélesztett betegek esetében nem igazolódott. Valószínű, hogy a beteg túlélését nem a szisztémás sejthalál, hanem egy jóval kisebb, kritikus funkciójú sejtcsoport károsodása határozza meg, mely a vizsgált markereinkkel nem különíthető el a kevésbé fontos sejtek pusztulásától. Az agy a többi szövethez képest alacsony relatív tömege révén valószínúleg alig járul hozzá a markerek emelkedéséhez, az általa okozott változás kimutathatatlan a teljes változáshoz képest. Emellett megjegyzendő, hogy a neuronok nem expresszálnak citokeratinokat; az intracerebralis vérzés, illetve stroke kapcsán észlelhető ccCK-18-szint-emelkedést [7-9] valószínúleg az alapbetegség egyéb szervekre áttevődő hatása okozza.

A sejthalálmarkerek a megfigyelési időszak során magas értéken stagnáltak (1. és 2. ábra). Feltételezzük, hogy a sejtek elhalása, a CK-18 és ccCK-18 felszabadulása időben elnyújtott folyamat, az eliminációval pedig egyensúlyt tartott a nekrózis okozta gyulladás, az intenzív osztályos kezelés és az egyéb szövődmények által kiváltott szekunder szövetsérülés. Az apoptózist jelző ccCK-18szint a túlélőknél tendenciózusan magasabbnak tûnt, így valószínü, hogy az apoptotikus sejthalál a túlélés szempontjából kedvezőbb a nekrózishoz képest. Elképzelhető, hogy a túlélők körében a sejteket érő károsodás mértéke még nem érte el a fatális szintet, és lehetővé tette az energiaigényes, élettanilag kedvezőbb sejthalálút, az apoptózis beindítását, kímélve ezzel a környező sejteket. Az elhunytak körében a sejteket érő stressz valószínúleg meghaladta ezt a kritikus szintet, és a sejtek nekrózissal elhaltak; náluk kevésbé volt lehetőség az apoptotikus folyamatok beindítására.

Roth és mtsai a szérum és a vizelet CK-18-szint-emelkedését figyelték meg CKD 3-5. stádiumú veseelégtelenségben [6], ami magyarázza a 3. ábrán látható, károsodott vesemúködés mellett tapasztalt, tartósan emelkedett CK-18-szinteket. Elképzelhető az is, hogy a károsodott vesemúködés miatt a CK-18 eliminációja is romlik, ami hozzájárulna ahhoz, hogy szintje a veseelégtelen csoportban magas maradjon.

A 4. ábrán feltüntetett CK-18- és a hemoglobinszint között észlelt szignifikáns negatív korrelációból arra következtethetünk, hogy magasabb hemoglobinszint esetén kisebb mértékű sejthalál történik. A 30 napos túlélésnek viszont épp az alacsony hemoglobinszint kedvezett (3. táblázat). Reanimáció során, a kritikusan meglassult véráramlás mellett a magasabb hemoglobinkoncentráció több oxigént tud biztosítani, így valószínúleg kisebb lesz a hypoxiás károsodás. Postresuscitatiós - már megfelelő hemodinamikájú - helyzetben ezzel szemben az alacsonyabb hematokritszint kedvezhet a mikrokeringésnek és a regenerációnak.

\section{Következtetés}

A sejthalálfolyamatokat tükröző CK-18 és ccCK-18 szintje jelentősen megemelkedik reanimációt követően, és a nekrózis mértéke az apoptózishoz viszonyítottan nagyobb, mint normálkörülmények között. Mindazonáltal a fenti paraméterek hasonlóan alakulnak a postresuscitatiós kezelést túlélő és a kezelés során elhunyt betegek között, és függetlennek látszanak a neurológiai károsodás mértékétől, valamint az egyéb körülírt szervfunkciós károsodásoktól is. A CK-18 és ccCK-18 sejthalálmarkerek így nem alkalmasak arra, hogy reanimáción átesett betegeknél segítsék a halálozás vagy a neurológiai károsodás prognosztikáját.

Anyagi támogatás: A cikk az Emberi Erőforrások Minisztériuma UNNKP-18-3-I. kódszámú Új Nemzeti Kiválóság Programjának támogatásával készült.

Szerzői munkamegosztás: Cs. B.: Irodalomkutatás, a vizsgálati terv kidolgozása, engedélyek beszerzése, adat- és mintagyưjtés, adatbázis-kezelés, statisztikai kiértékelés, a kézirat elkészítése. N. Á.: Irodalomkutatás, adat- és mintagyưjtés, adatbázis-kezelés. M. Zs., R. J.: Közremúködés a protokoll kidolgozásában, értesítés beteg érkezésekor, szakmai áttekintés. Cs. P., M. T.: Közremúködés a vizsgálati terv kidolgozásában, az eredmények értékelése, szakmai áttekintés. D. L.: A minták feldolgozása. H. R.: Laboratóriumi háttér biztosítása a minták feldol- 
gozásához, szakmai áttekintés. T. K.: Az eredmények értékelése, szakmai áttekintés. K. P.: A vizsgálat tervezése, az eredmények áttekintése, statisztikai és szakmai értékelés, a kézirat szövegezése. A cikk végleges változatát valamennyi szerző elolvasta és jóváhagyta.

Érdekeltségek: A szerzőknek nincsenek érdekeltségeik.

\section{Köszönetnyilvánítás}

Köszönettel tartozunk a Pécsi Tudományegyetem I. Sz. Belgyógyászati Klinikája, az Aneszteziológiai és Intenzív Terápiás Intézet, valamint a Sürgősségi Betegellátó Osztály dolgozóinak.

\section{Irodalom}

[1] Nikoletopoulou V, Markaki M, Palikaras K, et al. Crosstalk between apoptosis, necrosis and autophagy. Biochim Biophys Acta 2013; 1833: 3448-3459.

[2] Ku NO, Strnad P, Bantel H, et al. Keratins: biomarkers and modulators of apoptotic and necrotic cell death in the liver. Hepatology 2016; 64: 966-976.

[3] Lorente L, Martín MM, Pérez-Cejas A, et al. Higher serum caspase-cleaved cytokeratin-18 levels during the first week of sepsis diagnosis in non-survivor patients. Clin Chem Lab Med. 2017; 55: $1621-1629$.

[4] Adlbrecht C, Hoetzenecker K, Posch M, et al. Elevated levels of interleukin- $1 \beta$-converting enzyme and caspase-cleaved cytokeratin-18 in acute myocardial infarction. Eur J Clin Invest. 2007; 37: $372-380$.

[5] Feldstein AE, Wieckowska A, Lopez AR, et al. Cytokeratin-18 fragment levels as noninvasive biomarkers for nonalcoholic steatohepatitis: a multicenter validation study. Hepatology 2009; 50: 1072-1078.

[6] Roth GA, Lebherz-Eichinger D, Ankersmit HJ, et al. Increased total cytokeratin-18 serum and urine levels in chronic kidney disease. Clin Chim Acta 2011; 412: 713-717.
[7] Yuan ZG, Wang JL, Jin GL, et al. Serum caspase-cleaved cytokeratin-18 levels and outcomes after aneurysmal subarachnoid hemorrhage. J Neurol Sci. 2015; 359: 298-304.

[8] Gu SJ, Lu M, Xuan HF, et al. Predictive value of serum caspasecleaved cytokeratin-18 concentrations after acute intracerebral hemorrhage. Clin Chim Acta 2016; 452: 124-128.

[9] Molnár T, Böröz K, Berki T, et al. Subacute elevation of plasma level of caspase-cleaved cytokeratin-18 is associated with hemorrhagic transformation and functional outcome in ischemic stroke. J Stroke Cerebrovasc Dis. 2019; 28: 719-727.

[10] Nolan JP, Soar J, Cariou A, et al. European Resuscitation Council and European Society of Intensive Care Medicine Guidelines for Post-resuscitation Care 2015: Section 5 of the European Resuscitation Council Guidelines for Resuscitation 2015. Resuscitation 2015; 95: 202-222.

[11] Sandroni C, D'Arrigo S, Nolan JP. Prognostication after cardiac arrest. Crit Care 2018; 22: 150.

[12] Safar P. Resuscitation after brain ischemia. In: Grenvik A, Safar P. (eds.) Brain failure and resuscitation. Churchill Livingstone, New York, NY, 1981; pp. 155-184.

[13] Rohlin O, Taeri T, Netzereab S, et al. Duration of CPR and impact on 30-day survival after ROSC for in-hospital cardiac arrest - a Swedish cohort study. Resuscitation 2018; 132: 1-5.

[14] Taccone FS, Horn J, Storm C et al. Death after awakening from post-anoxic coma: the "Best CPC" project. Crit Care 2019; 23: 107.

[15] Pachys G, Kaufman N, Bdolah-Abram T, et al. Predictors of long-term survival after out-of-hospital cardiac arrest: the impact of activities of daily living and cerebral performance category scores. Resuscitation 2014; 85: 1052-1058.

[16] Hofer S, Brenner T, Bopp C, et al. Cell death serum biomarkers are early predictors for survival in severe septic patients with hepatic dysfunction. Crit Care 2009; 13: R93.

(Csiszár Beáta dr., Mágocs, Dózsa György utca 48/A, 7342 e-mail: cs.bea1993@gmail.com)

\section{"Potest uti adversis numquam felicitas." (A szerencsések nem tudják, hogy a bajjal miként bánjanak.)}

A cikk a Creative Commons Attribution 4.0 International License (https://creativecommons.org/licenses/by/4.0/) feltételei szerint publikált Open Access közlemény, melynek szellemében a cikk bármilyen médiumban szabadon felhasználható, megosztható és újraközölhető, feltéve, hogy az eredeti szerzỏ és a közlés helye, illetve a CC License linkje és az esetlegesen végrehajtott módosítások feltüntetésre kerülnek. (SID_1) 